\title{
Teachers' Understanding and Attitudes towards Communicative Language Teaching Method in ESL Classrooms of Zambia
}

\author{
Patricia Makina Zulu \\ The University of Zambia
}

*Corresponding Author: Patricia Makina Zulu, The University of Zambia

\begin{abstract}
The study aimed at establishing teachers' understanding and classroom application of the Communicative language approach to English language teaching. The study was anchored on two objectives namely: teachers understanding of CLT and Teachers' attitudes towards toward the communicative language teaching method. A qualitative research design was employed through the use of face to face interviews. 40 teachers of English who were purposively sampled participated in the study. The findings were analysed thematically. The findings from the study indicated that teachers had low to moderate understanding of the Communicative language teaching method. Other teachers held misconceptions about the method which further misguided their classroom application. One misconception that the teachers held was that CLT encouraged errors and neglected grammatical correctness of utterances. In addition, while most teachers held negative attitudes towards the method, some of them held positive attitudes towards CLT. These attitudes had implications on the aspects and quality of CLT which teachers used. Those who held negative attitudes claimed that CLT was too involving and that it was not modelled on the Exam in terms of its content and general demands. Arising from the findings, the study recommended that there was need for CPDs among serving teachers to acquaint them with the classroom demands of the Communicative approach to language teaching and possibly change their attitudes too.
\end{abstract}

\section{BACKGROUND}

The Zambian secondary school syllabus recommend the communicative language teaching method for the teaching of English in secondary schools. Historically, the Communicative Language Teaching approach (CLT) was developed to try and remedy the Text Based approach and the Situational approach. Hymes (1972) argued that the goal for language learning under the communicative method is developing communicative competence in learners. As a departure from cognitive code approach, Richards (2006:9) explained that under CLT, "While grammatical competence was needed to produce grammatical correct sentences, attention shifted to the knowledge and skills needed to use grammar and other aspects of language appropriately for different communicative purposes, such as making requests, giving advice, making suggestions, describing wishes and so on." From this preposition we can deduce that CLT is still concerned with grammatical correctness of utterances but with an added dimension of function. Language is used as a tool to perform different functions such as asking for forgiveness, making requests, asking for directions and giving directions among other things. According to Littlewood (1981:1) "One of the most characteristic features of communicative language teaching is that it pays systematic attention to functional as well as structural aspects of language'. Thus, CLT refers to both the processes and goals in the classroom learning where communication is the ultimate goal of learning. It recognises the use of grammar in language but more so their appropriateness in usage: That is, it takes into consideration the appropriateness of the language when used with people of different ages and status and the manner in which a person expresses what he or she intends to communicate. This involves the tone of the word and the selection of the words to be used appropriately. Richards (2006:13) summarises the features of CLT as follows;

a. Make real communication the focus of language learning.

b. Provide opportunities for learners to experiment and try out what they know.

c. Be tolerant of learners' errors as they indicate that the learner is building up her or his communicative competence. 
Teachers' Understanding and Attitudes towards Communicative Language Teaching Method in ESL Classrooms of Zambia

d. Provide opportunities for learners to develop both accuracy and fluency.

e. Link the different skills such as speaking, reading and listening together since they usually occur so in the real world.

f. Let students induce or discover grammar rules.

From the principles, it can be argued that CLT proposes a holistic approach to language learning than the traditional methods such as audio lingual which views errors as a deterrent occurrence to language learning which was undesirable and should be corrected immediately. The communicative Language Teaching method views errors as a normal occurrence in the language learning procedure.

In this method, the teacher does not take the central role but takes the role of the facilitator, where the pupils participate more through interaction with each other in situations which depict real life. It allows the pupils to use language freely. The role of the teacher is to provide opportunities in which learners can practice speaking, listening and reading skills in a manner which fosters communication. Through practice, the learners acquire accuracy and fluency of the English language. Wali (2009) states that the Communicative approach uses a variety of communicative activities such as group work, pair work, class discussion, debate, role play and simulation. The definition by Wali suggests that the approach should be used with other approaches to make teaching of the second language easier. This would develop an effective teacher of language. This approach puts emphasis on interaction among learners and the aim is for the learners to use the target language in real life situations. That is to say, learners must be in a position to apply the grammatical rules learnt in performing functions in the target language.

The communicative language teaching approach combines the grammatical and semantical branches of linguistics and therefore seemed more favourable to teach the target language. Moreover, since the communicative language teaching method did not put much emphasis on the correction of errors but emphasised effective communication in situations outside the classroom, the communicative language approach seems more appropriate for a multilingual country like Zambia as it allows strategic code switching and give learners a lot of opportunities for learners to practice the target language. English being the official language in Zambia, and taught as an important subject to the learners, has to be taught in such a way that the learners can use it to function in real life situations. CLT is more favourable to the Zambian situation as it combines principles from other methods and making it eclectic in practice.

Several studies have been conducted on the classroom application of the approach. Mareva and Nyota (2012) conducted a study titled, "Structural or Communicative Approach: A Case of English Language Teaching in Masvingo Urban and Peri-Urban Secondary schools. The purpose of the study was to investigate the teaching of English as a second language (ESL) in Masvingo, Zimbabwe. It sought to find out if the traditional structural approach with emphasis on grammatical competences, still had influence on English language teaching in Zimbabwean secondary schools in Masvingo. The research established that teachers did not use CLT as much as the structural approach and traditional approaches. The assumption was that the non-use of CLT was due to teachers' ignorance of the principles of CLT. Mareva (2012) did a follow up of the study he did with Nyota (2012) and looked at the teachers' conception of communicative language teaching. The research was a case study of Masvingo district and it aimed at finding out if teachers understood CLT in order to use it effectively. The findings showed that the teachers had a fair understanding of what the approach was all about. However, he also noted that the teachers had some misconceptions of CLT which suggested a controversy to its implementation. The following were some of the misconceptions established;

a. CLT implies the teacher abdicates his role as a teacher.

b. CLT eschews the teaching of grammar.

c. CLT means pair work and group work in every lesson.

d. CLT places too much emphasis on the development of speaking and listening skills at the expense of reading and writing.

e. Material for CLT is scarce and expensive.

f. CLT means the language teacher should ignore learners' errors. 
g. CLT places too many demands on the teacher.

h. CLT aims at achieving native like pronunciation in second learners.

Even though teachers in Masvingo seem to know ideally what CLT entails, they do not fully understand the principles of how the theory worked. Like the findings in the study which Mareva did with Nyota previously, the assumptions made by teachers indicate a certain level of ignorance on the understanding and consequently implementation of CLT principles. In chapter four of my study I will show how teachers in Mufulira understand CLT and if they held any misconceptions.

Ridge (1992) also did a research on CLT whose title was, "Communicative Language Teaching: Some Challenges for Teachers in South Africa." The purpose for the study was to find out if teachers were adequately trained to teach English using CLT or not. Ridge argued that "the focus for the teacher colleges should be on education rather than training." From this statement Ridge seems to be making an assumption that the teacher training colleges are not preparing the teachers well to implement CLT principles in class. The article established that teachers have had problems in implementing CLT satisfactorily as highlighted by (Ridge 1992, Jessop; 1994, Makoni 1994; Vander Merve 1994) and the assumption was that South Africa did not have teachers whose proficiency in the English language was of high standard. Karras and Wolhuter (2015:13) states that, "There seems to be a general agreement that the processes of teaching and learning are highly dependent on quality teachers." Teacher preparedness is key in the implementation of any teaching method by the teachers and as a researcher I share the same views as the other researchers who have acknowledged the importance of teacher preparedness. Nyarigoti (2013) did a study in Kenya on the Continuing Professional Development (CPD) for English teachers. The study aimed at establishing the teachers' views, needs and challenges concerning CPD. The study established that the training the teachers got during Pre-service training was insufficient and to some extent outdated. From Nyarigotis' study we can establish that the teachers are not effectively trained and that they don't feel confident in the training they received. Unfortunately from the studies conducted in Africa especially, teachers seem not to be well prepared to employ CLT. This study will try to establish if this is the case with teachers in Mufulira.

Taking Kashoki's view into consideration, the Zambian child could not speak nor seem to be motivated because the teachers continued to teach the learners using the traditional approach and did not teach grammar in real social context in which utterances are made. Learners should acquire grammatical rules simultaneously with communication. If learners are taught the English language in the context that is meaningful, then they would gradually learn to express themselves as opposed to what was suggested by Chishimba and Kashoki. Since the two studies were done about 28 years ago, my study in the chapters to come will show if teachers still hold the same views as theirs.

CLTs' aim is to ensure learners are able to communicate fluently and effectively. Therefore, as the learners begin to express themselves, the focus is not so much on their grammatical errors but on the ability for them to put their message across. Unlike the assumption that Kashoki had that Zambian children are not ready for CLT approach in their classroom, CLT does allow the children to use their local language when the English vocabulary falls short. The teacher would later come in with the correct words in English that were supposed to be used, that way pupils would not shy away from communicative activities.

The effective implementation of CLT in the teaching of English is heavily dependent on the teachers' attitude towards the communicative language teaching method. Banda (2015) stated that there could be many aspects teacher that could affect the choice of techniques that a teacher can employ in a classroom situation. From this statement, we can suppose that the teacher has the power to pick the technique that he/she feels is adequate for the delivery of a lesson. This being the case, we can argue that the methods and techniques suggested by the syllabus are not really binding as the teacher is free to choose the techniques to employ. Banda (2015) agrees with the findings on class size which is forwarded by Hui by stating that "while group work would be recommended as an effective way of making pupils participate in a lesson, one cannot use group work in a class with 100 pupils. It is in such context that one must use one's knowledge prudently in order to teach effectively." The statement made by Banda seems to suggest that the group work technique in itself is good however 
whether it is applicable in all situations is not known. My study will endeavour to establish if CLT is applicable in secondary schools in Mufulira.

A study conducted by Mwanza (2016) in Lusaka area on Eclecticism, indicated that teachers had limited understanding of the approach. While some teachers were able to define the approach correctly, they were not able to apply it correctly in the classroom. Even though his study was on eclecticism, the principles on which CLT and eclecticism are founded are very similar. From Mwanzas' study it was observed that teachers had mixed attitudes towards the approach. The findings also indicated that some time felt the approach was time consuming and that the use of different methods in a lesson could confuse the learners. The participants from the study seem to be under the impression that the use of different methods would happen haphazardly, they neglect the cardinal aspect of teaching which is lesson planning. If a lesson is well planned there is no way the learners could be confused as the lesson would be planned in such a way that learners would be able to follow and learn easily. The study also established that the teachers used the teaching methods devoid of real life situations. The teachers were more interested in constructing sentences. The communicative way of teaching requires that the teaching of English language be done in manner which real life use of language.

The Zambian senior secondary syllabus recommends it to be used at secondary school. Curriculum Development Centre (2012:4) states that "The senior secondary school English language syllabus recommends the use of the Communicative approach in tandem with the text based integrated approach." This implies that the goal of English language teaching is communication in which learners should attain communicative competence. In this vein, teachers are supposed to be familiar with the principles of the method and hold positive attitudes towards the method. However, whether the teachers understand, appreciate it or even hold positive attitudes towards the method is not known.

\subsection{Statement of the Problem}

The Communicative Language Teaching Method is the main recommended teaching method by the senior secondary school English language Syllabus. The implication is that teachers are supposed to be trained in the method and possess thorough knowledge about the principles of the method. Further, since teachers attitudes are central to the success of teachers implementation of policy or curriculum (Mwanza, 2016, Mwanza, 2018), it is also expected that teachers of English in Zambia hold positive attitudes toward CLT. However, it is not known how teachers actually understand the method and what attitudes they hold towards the method.

\subsection{Purpose of the Study}

The study sought to establish teachers' understanding and attitudes toward the Communicative language Teaching Method in selected secondary schools of Mufulira District.

\subsection{Objectives}

The Objectives of the Study were to Establish:

- Teachers' understanding of Communicative Language Teaching.

- Teachers' attitudes towards Communicative Language Teaching Methods.

\subsection{Research Question}

Arising from the objectives, the following are the research questions:

- How did teachers understand Communicative Language Teaching?

- What attitudes do teachers hold towards Communicative Language Teaching Method?

\subsection{Significance of the Study}

This study is significant in that the research outcomes have the potential of bringing out the understanding of CLT by the teachers and this may inform the teacher educators of the manner in which their institutions implement CLT. In addition, it may also bring to the attention of the policy makers about the competences teachers have in CLT. It will also contribute to the body of knowledge which could be referred to in future scholarly studies. 


\section{Methods of Data Collection AND Analysis}

The study used the qualitative design. This was done in order to generate teachers' verbal responses on how they understood the communicative language teaching method. Using purposive sampling, 40 teachers of English were sampled to participate in the study. The participants were drawn from Mufulira District of the Copperbelt Province in Zambia. Interviews were the main method of data collection and the interview guide was used as an instrument. The data was analysed by use of thematic analysis. Patton and Cochran (2002:23) explain thematic analysis as "analysis that looks across all the data to identify the common issues that occur, and identify the main themes that summarise all the views you have collected." In my study, I grouped the data into two themes stemming from the two study objectives. The themes were formed by grouping similar findings under one theme. What this means is that regardless of the source of the data, if the findings were similar they were put under one theme. To do this I took time to read through and listen carefully to all the data I had collected. Hancock etal (2010:31) states that if the researcher is clear what question he/she is set to address, it will be easier to make sense of the mountains of data you have generated and to present it in a meaningful and interesting manner. Having made themes using my study objectives, it was easier for me to put the data into the right themes and in a coherent manner. Data analysis also entailed that the researcher interpreted and analysed the data which was collected in order to present it in a comprehendible manner.

\section{Presentation of Findings}

The following section presents the data. As hinted above, the data is presented under the two study themes.

\subsection{Teachers' Understanding of the Communicative Language Teaching Method}

The first objective was to establish the teachers' understanding of CLT. It is imperative for this study to establish whether the teachers actually understood what Communicative Language Teaching is all about and if they are aware of the techniques used in the delivery of English lessons in the classroom. Without the understanding of CLT, the application of CLT techniques is almost impossible. Therefore, the findings will be of much help to the study even to understand teachers use and attitudes.

The teachers who were interviewed showed that they had some understanding of what CLT is all about in general. The teachers expressed different levels of understanding of what CLT entails in lesson delivery. The teachers understood CLT to be teacher centred method where the teacher took the role of facilitator and pupils interact through the use of techniques such as role play and group work. Those who showed understanding of the communicative language teaching method had the following to say:

T1: Communicative Language Teaching approach is an approach where pupils are allowed to interact with each other through situations given. The teacher can give the pupils group work or questions for them to discuss.

T2: This is a method used to teach language basing on the communicative purposes.

\section{T3: From the word communicative itself, it's more like discussion method.}

T4: I think the focus in CLT is more on the learner. It's about having the connection with the learners as you teach.

T5: It is an approach where you communicate with the pupils. It is not based on you doing all the talking.

T6: CLT is an approach which deals with tactics of approaching teaching.

T7: This is based on one on one communication, that is, at times you can use question and answer type of teaching.

T8: I can say that Communicative Language Teaching is a method where a teacher acts as a facilitator in the classroom. 
Teachers' Understanding and Attitudes towards Communicative Language Teaching Method in ESL Classrooms of Zambia

Most of the teachers explained that CLT involved the pupil interaction and that it was an approach which is pupil centred. The following were some of the responses:

T9: Communicative Language approach is an approach where there is interaction. The pupils are put in situations where they are supposed to deliver the message.

T10: You allow the learners to develop the skills of interaction so that when they graduate they use it to communicate in businesses and even at work.

T11: The Communicative Language Teaching is an approach to language teaching that emphases interaction as both means and ultimate goal of study.

T12: CLT emphases on the communication and not so much on the mistakes of the pupils. The teacher allows the pupils to make mistakes as they talk in English.

T13: Communicative Language Teaching is an approach which involves the pupils a lot. It has activities which pupils act in and communicate. The teacher can use group work so that the pupils are involved.

The teachers also explained that CLT was about helping the learners to communicate meaningfully rather than being grammatically correct all the time. Consider the following responses:

T13: The understanding of CLT is that the meaning of the sentence is most important even if it is wrongly said or grammatically wrong.

T14: This is a method used to teach language basing on the communication purposes. The teacher involves the pupils in activities such as group work and debate so that the pupils can learn.

Although some respondents showed some understanding of the method, other did not. They clearly stated that they could not explain what CLT was all about. They literary said they did not know or could not remember. One teacher said:

T15: Ba Makina (Ms Makina) I can't remember what CLT is, I know we did it a bit at college but

I have forgotten unlike I go and read maybe.

However, when it came to techniques used to deliver CLT lessons, some teachers seemed to be unsure of the techniques used in CLT lesson delivery. When asked about the techniques used in lesson delivery, some teachers said "teachers' exposition and gestures." While others said individual work and question and answer. Some teachers even said teaching materials and role play. From the responses above we can see that even though the teachers have an idea of CLT is, they don't seem to know the techniques used during lesson delivery. Those that seemed to know the techniques were only limited to discussion, role -play and group-work. The majority of teachers seemed to be sure of group work as the technique used in CLT lesson delivery.

Some teachers had some misconceptions about CLT and the application of the method in the classroom. The teachers indicated that for CLT to be applied in the classrooms, the learners needed to be very fluent in English. They also stated that CLT neglected the grammatical correctness of the sentences as it encouraged errors by the learners. Some of the respondents stated that:

T16: Madam aba abana twakwata (these children we have) can't speak English so you find that fail to use discussion method with them. You find that in a class only the same pupils will participate in such activities, the rest just make noise."

T17: This method destroys the pupils because it makes the pupils use broken English in the end you find that the pupils cannot speak proper English kabili (because) you can't correct the pupil's mistakes.

T18: Using CLT in lesson delivery is not helpful because it allows the grammatical errors that pupils make therefore, the pupils continue making the same errors over and over. The approach makes the pupils to be comfortable even their English is grammatical wrong. They say "as long as you get what am saying." It is because of this approach that we are having grade $12 \mathrm{~s}$ who can't speak correct English and very soon we will have teachers who can't communicate effectively in English. 
The findings show that while some teachers understood the method, others did not while another section of teachers held misconceptions about the method.

\subsection{Teachers' Attitudes towards Communicative Language Teaching}

The study also aimed at establishing teachers' attitudes towards CLT. This research objective was important for this study because teachers' attitudes play a big role in the implementation of education policies as well as teaching methods stipulated in the syllabus. To establish the teachers' attitudes, the researcher used the face to face interview method to interview the teachers of English. The interview was guided by semi structured questions for easy flow of the interview. To ensure that the data collected was accurate, the researcher employed the use of a note book and an audio tape recorder. The tape recorder was used to make sure the researcher had the correct information since it is not possible to write everything the participant says.

From the interview, the researcher observed that there were different attitudes which teachers held regarding the application of CLT in the classroom. There were some positive attitudes, negative attitudes and some teacher's attitudes were neutral.

Some teachers held positive attitudes and said that it was an effective way of delivering English lessons. Consider the following responses:

T25: The approach is worthwhile, the more reason we teach English is for Communication, in the market they will use appropriate language, at the bank, and they will be able to know how to approach the manager because they will apply what they learnt in class.

T26: CLT is effective as it usually gives you the immediate response from the pupils. It helps you to know the pupils' understanding and how difficult. The topic was. You are also able to tell if pupils can communicate using English.

T22: I use CLT in every lesson I teach, be it in composition, comprehension and even summary. Learners are asked oral questions. In every lesson you expect pupils to communicate and as they are communicating that is CLT.

The teachers noted that the approach allowed for pupils to interact with each other and in the process helped the pupils to learn English. They stated that CLT allowed for full pupil participation.

However, there were some teachers who were not so keen on CLT techniques as way of lesson delivery. They explained that the method was not practical in Zambia especially in public schools. Other said that the method can't produce pupils who can communicate and that it was therefore a waste of time using CLT in Zambia. Consider the following responses:

T27: CLT itself is okay however, it does not work so well in our Zambian situation especially in government schools, the pupils we have can't communicate in English therefore, it is hard to use role play or discussion.

T28: CLT is just a waste of time as pupils still can't communicate in English. These pupils we have need to be drilled for them to understand. To me Audio Lingua is better as it teaches pupils how to pronounce words correctly.

T29: It is not a very good method as our classes are over crowed in government schools; it makes group work difficult to do as pupils are too many. If we have to use CLT it will mean we will not cover much of the syllabus as the methods take a lot of time. The pupils make a lot of noise during discussions and disrupt the lesson. You will also find that it is the same pupils who participate in these activities as most of them cannot express themselves in English. CLT is only effective if the pupils can speak English otherwise it is a waste of time.

T24: I don't use CLT when teaching English because it is just a waste of time. I teach my pupils for exam purposes, am a grade 12 marker and I know what markers look for and my pupils do very well in the exams.

T19: I rarely use it in my lessons as the classes are too big and it takes a lot of time to prepare for the lesson, even when teaching you find you don't finish the topic on time. 
Teachers' Understanding and Attitudes towards Communicative Language Teaching Method in ESL Classrooms of Zambia

There were some teachers who were neutral on the use of CLT in the English lessons. They were not too sure if the method was effective or not. They preferred to remain on the neutral on the matter. Two respondents said the following respectively:

T31: Communicative Language Teaching method can be effective sometimes depending on the topic which on is teaching. Sometimes it is not really a good method as it's not all topics which you can use CLT. So I can say it can be both good and bad way of teaching.

T32: I can't really say if it is good or not madam. Sometimes it depends on the topic you are teaching and the class which you are teaching. As you know some pupils cannot speak English so in that case it is not but in classes where pupils can speak English it is good, especially in private schools where pupils speak English.

In Conclusion the study established that the teachers had different attitudes towards CLT. Those that held positive attitudes indicated that CLT was a good method as it helped the learners to participate in the lessons. Those that held negative attitudes felt it was a waste of time as it did not enable the learners to pass their exams. Others were neutral and expressed that it was either good or bad depending on the topic one was teaching.

\section{DISCUSSION OF FINDINGS}

The following section provides an analysis of findings in line with the two research objectives and one emerging theme from the study.

\subsection{Teachers' Understanding of Communicative Language Teaching Method}

To find out how the teachers understood CLT, I used the face to face interview technique. I interviewed the teachers as individuals and I explained to them the purpose of the interviews before hand. The teachers interviewed expressed different understandings of CLT. Some teachers expressed some understanding of CLT. 21 respondents understood CLT ideally, that is, they had the general idea of what CLT was all about. The respondents stated that CLT was a learner centred method which encouraged the learners to interact among themselves. From the interview conducted and with the aid of research questions, the findings established that most of the teachers showed partial knowledge of what the communicative language teaching method entails. When asked to explain what they understood by CLT, most of them could not explain effectively what CLT is. Some respondents were aware that CLT was a learner centred method. However, they showed little knowledge of how the lesson can be made more interactive. Furthermore the respondents only viewed CLT in terms of group work and class discussion techniques and hence leaving out other equally important elements such as multiplicity of teaching materials, translanguaging among multi-linguals and teaching language as a whole by focusing both on the form and the function. Therefore, it can be stated that the actual understanding of CLT by the teachers was very shallow.

The teachers were not fully conversant with the principles of the Communicative Language Teaching method and as such they could only give fragments of what the method was all about. The limitation of CLT knowledge by the teachers paved way for misconceptions which were revealed during the interviews.

The teachers who were interviewed in Mufulira district seemed to have some misconceptions about CLT just like the other studies from other scholars indicated. The teachers held views that CLT eschewed the teaching of grammatical correctness of utterances and that the method condoned errors. Brown (1994:245) gives the correct principle of CLT by stating that, "Fluency and accuracy are seen as complementary principles underlying communicative techniques. At times, fluency may have to take on more importance than accuracy in order to keep learners meaningfully engaged in language use."From Browns' supposition, it can be stated that CLT advocates for accuracy (grammatical correctness) as much as it advocates for fluency. However, to get the learners to the level of communicative competence which is desired, the teacher has to allow the learners to interact with minimal interruption so that the flow of conversation can be as normal as possible, errors can be noted and thrown back to the class for correction through discussion. It is worth remembering here that CLT proposes learning of English to happen in situations which are as natural as possible. Respondents also stated that the communicative language teaching method could only work in schools were 
learners' English proficiency was good. Stating therefore that the low proficiency in English by learners especially in government schools made the implementation of CLT almost impossible. Richards and Rodgers (2001) states that language is created by the individual, often through trial and error). This is one of the principles of CLT unlike what the participants suggested that errors are a barrier to English language learning. Banda and Mwanza (2017) agree with this by stating that home languages and literacies should be allowed in the classroom as stepping stones to accessing learning. From this we can establish that the learners' low English proficiency is not a hindrance to the application of CLT in the classroom but rather the teacher should tap on the learners' knowledge of the local language to teach English. As the Constructivist theory suggests, learning depends on the sign systems (language, writing system, work of art...) that individuals grew up with. These symbols help the learners to think, communicate and solve problems (Woolfolk 2014). The need for code switching in the early stages of English learning can therefore not be over emphasised as it is merely the building block of the English language learning process. Some teachers felt that CLT can only be used to teach grammar but could not be used to teach writing skills and other macro skills contrary to what the tenets of CLT proposes. Most of the teachers understood CLT to be group work and pair work. While group work and class discussion are part of the classroom activities under CLT, they are not the only ones. Thus, for teachers not to mention multiplicity of teaching materials, teaching all four language skills, teaching from simple to complex as well as recognition of one's familiar language as part of the learner centred paradigm shows that they lacked adequate understanding and appreciation of CLT. These findings are similar to Mwanza (2017) who also found that teachers of English in Zambia held misconceptions about the Eclectic Method to English language teaching and that their misconceptions affected the way they taught English.

Some teachers also stated that CLT gives the teachers more work as it takes time to prepare and that it was time consuming. The issue of CLT being time consuming suggests lack of good time management and poor lesson planning on the part the teachers as the need for lesson preparation cannot be done away with regardless of whichever approach or method a teacher opts to use. The data presented indicated that the teachers did not prepare adequately for their lessons and therefore they failed to apportion their time well. These misconceptions as forwarded by the teacher suggest that the teachers will interpret the techniques wrongly in class and the obvious outcome would be that what the teachers believe to be CLT application may actually not be correct. These findings are consistent with Mareva (2012) who conducted a research in Masvingo (Zimbabwe) and the purpose was to establish the teachers' conception of communicative language teaching. The findings indicated that the teachers had a fair understanding of CLT. However, he also indicated that the teachers in his study had misconceptions similar to those in Mufulira district. The teachers from both studies indicated that CLT demands for teaching materials which are not readily available and expensive. This supposition is not true as CLT advocates for authentic communication situations which can be created by the teacher by mere explanation or use of the chalk board. This supposition by the teachers show that the teachers had no understanding multimodality and semiotic modality.

Thus, in summary, it can be reiterated that while some teachers showed fair understanding of the communicative language teaching method, others did not while others held misconceptions of the method. Lack of understanding and holding misconceptions about the method imply that teachers would either not apply the communicative language teaching method or that they would wrongly apply it is they attempted to do so.

\subsection{Teachers' Attitudes towards the Communicative Language Teaching Method}

One of the research objectives for this study was to find out the attitudes teachers have towards CLT. Attitudes play a big role in the adaptation of the methods and techniques teachers employ in their lesson delivery. To find out what views the teachers held, I used the one on one interviews. The teachers interviewed expressed different views on the use of CLT in the lesson delivery. Most of the teachers interviewed for this study stated that CLT is a good method for teaching English in general. However, when asked if it was a good method for them to use in the Zambian situation, most of the teachers said it was not ideal. The reasons that were forwarded for this were that the learners were just too many in their classes. The others felt CLT was not helpful in terms of examination preparations. They indicated that CLT was time consuming and therefore, made it difficult for them to meet their lesson objectives. 
There were some teachers who held complete negative attitudes on CLT altogether. The teachers interviewed expressed that, CLT was a waste of time. The important thing is to drill pupils to pass the exams. This sentiment was brought out by a teacher who is a marker at grade 12 level. According to this teacher (grade 12 marker) there was no need to teach the pupils to be communicatively competence as he was aware of the way examinations are structured. This view was shared by other teachers who felt that what was important was for pupils to pass the final exams and that was the only way to judge who a good teacher was. The other teachers felt that CLT was not a good method as it did not help much in the producing of fluent English speaking learners. One teacher stated, CLT was not a good method and that was why they were having grade 12s who couldn't speak English because CLT allows them to speak broken English.

The findings reveal that the goal of English teaching as held by the teachers was to enable pupils to pass their final exam. The learning of English for communicative purposes was secondary to passing exams. This was because according to the teachers, a good teacher was one who produced the highest number of learners with high grades. Having a class of learners who are competent orally is not a plus on its own unless they can pass the tests as well. The pressure came from the higher officers who rated the school performance on the pass rate. Since the exams were also structural framed, the teaching of oral skills and listening skills were not seen to be important. Chishipula (2016) also had similar findings on the attitudes of the teachers to teach English for exam preparations. The implications of these findings are that the teachers were not teaching English in a comprehensive way. They are still committed to the traditional methods of teaching which they felt prepared the learners better for the examinations. Even though teachers in some instances held positive attitudes, they did not always apply CLT as argued by Hui (1997) who indicated that the lack of appropriate materials and equipment, administrative constraints among others led to the mismatch between attitudes and implementation.

The findings in my study are shared by many researchers. Othman (2016) observed that teachers' seem to prefer traditional methods as compared to CLT. These findings are shared by Vongxey (2013) who also observed in his study that the negative attitude arose from low proficiency in English by the teachers who lacked proper preparedness. From this, we can tell that there are a number of reasons why teachers may hold different attitudes.

There is need for deliberate efforts especially by standard officers in the district to explain to teachers the advantages of using CLT in English language teaching so that their attitudes can change. This is particularly important because as Mwanza (2017) noted, teachers' attitudes towards a method or education policy have a direct effect on the implementation and success of such a method or policy. There is also need for school based or zonal based Continuing professional development activities because pre-service teacher training is not complete in itself (Manchishi and Mwanza, 2013,; Manchishi and Mwanza, 2018) and even teacher training strategies such as peer teaching have labelled as inadequate to fully prepare teachers (Manchishi and Mwanza, 2016). This is the reason why teachers' capacity building activities such as CPD and professional workshops should be promoted in schools.

In summary, it has been sown that while some teachers held positive attitudes, others held negative to neutral attitudes. As a way forward, teachers ought to be sensitised on the advantages of CLT and they also need capacity building on what the method means and how it can be applied in the classroom while avoiding the perceived challenges.

\section{CONCLUSIONS AND RECOMMENDATIONS}

The study used the qualitative research method and employed the face to face technique, lesson observation and lesson plan analysis. The sample size consisted of 40 senior secondary school teachers from six secondary schools. The sampling technique used was purposeful as the study required only those teachers handling secondary senior classes. The conclusion will be summarised according to the research objectives accordingly.

\subsection{Teachers Understanding of Communicative Language Teaching}

The data from the interviews revealed that 21 of the teachers had a clear understanding of what CLT was about. They indicated that CLT was learner centred and it involved learner interaction with the 
use of techniques such as group work, role play, pair work and debate. 16 of the respondents had partial to no understanding of what CLT was all about. The findings from established that the teachers had misconceptions about CLT and this was noted from the responses they gave. The misconceptions led to the misinterpretation of the method in the classroom. Of the interviewed teachers five indicated that they had no knowledge of what CLT was. This finding led to the non-use of CLT in the classroom.

\subsection{Teachers' Attitudes towards Communicative Language Teaching Method}

The teachers' held different attitudes towards CLT. From the data gathered from interviews, teachers held positive, negative and neutral attitudes towards CLT. The teachers who held positive attitudes were in favour of using CLT and they indicated that CLT was a good teaching method. However, those that held negative attitudes stated that the method was well suited for classroom use especially government schools were the numbers of learners were too large. Others who held negative attitudes also stated that the method was a waste of time as it did not do much for exam preparation of the learners. While those who held neutral attitudes indicated that CLT was neither here nor there, it all depended on the lesson one was teaching. They stated that sometimes it was useful while in other instances it was not. They did not show much enthusiasm towards the method.

\section{RECOMMENDATIONS}

Arising from the findings, the following recommendations can be made:

a. Teachers' continued development programs to be revamped and include more demonstrations on how to apply CLT especially in multilinguala and overclouded classrooms.

b. The government/school administrators to minimise the number of learners in each class to make the application of CLT more effective by building more schools to accommodate more pupils.

\section{REFERENCES}

[1] Adedimeji, M. A. (2011). Towards a Pragma-integrative Approach to the Teaching of 'Use of English' in Nigeria: A case for Human Development. In Opoku-Agyemang. $K(e d)$. Culture, Science and Sustainable Development in Africa. Cape Coast: University of Cape Coast Press. 178-198.

[2] Al Magid, M. A. (2006). The Effect of Teachers' Attitudes on the Effective Implementation of the Communicative Approach in ESL Classrooms.Masters' Dissertation.University of South Africa.

[3] Anthony, E.M. (1963). Approach, Method and Technique in English Language Teaching, 17(1): 63-67

[4] Banda, D. (2015). The Application of Approaches, Methods and Techniques in the Teaching of the Four Language Skills. Unpublished LSE 232/332 module 2.

[5] Banda, F and Mwanza, D. S. (2017). Language-in-education policy and linguistic diversity in Zambia: An alternative explanation to low reading levels among primary school pupils. In Banja, Madalitso Khulupirika (ed.). Selected readings in education, 109-132. Lusaka: University of Zambia Press.

[6] Chishimba, M. M. (1989). The Communicative Approach to Language Teaching: Themes and Approaches for Zambian Schools. Zambia Educational Review. 6 (1)

[7] Chishipula, J. (2016). Factors Hindering Teachers of English Language From Implementing Communicative Language Teaching (CLT) Approach: A Case Study of Selected Secondary Schools in Chongwe District. Zambia. Lusaka: University of Zambia.

[8] Curriculum Development Centre.(2012). Senior Secondary School English Language Syllabus. Lusaka. CDC.

[9] Hancock, M. P., Russell, S. H., and McCullough, J. (2007) Benefits of Undergraduate Research Experiences Sciences. Washington, 316 (5824): 548-549

[10] Hui, L. (1997). New Bottles, Old Wine: Communicative Language Teaching in China, Forum, 35/4, PP. 38-47, retrieved from http://e.usia.govt/forum/vol35/no4/p34.htm.

[11] Hymes, D. (1972). On Communicative Competence. In J. B. Pride and J. Holmes (eds), Sociolinguistics, pp. 269-93. Harmonsworth: Penguin.

[12] Hymes, D. (1979). On Communicative Competence. In Brumfit, J. and Johnson, K. (Eds), (1979). The Communicative Approach to Language Teaching. HongKong: Oxford University Press: 5-26.

[13] Jensen, L. (2001). Planning Lessons. In M. Celce Murcia \& L. McIntosh (eds). Teaching English as a Second or Foreign Language. Boston, MA: Heinle\&Heinly. 
Teachers' Understanding and Attitudes towards Communicative Language Teaching Method in ESL Classrooms of Zambia

[14] Kashoki, M. (1978).Between Language Communication in Zambia. In Kashoki M., and Ohannessian, SE, Eds Language in Zambia. London: International African Institute: 123-143.

[15] Kasonde, N.S. (2013). Writing a Research Proposal in Education Research. Lusaka: University of Zambia.

[16] Kilfor, W,R. \& Van der Walt, C. (1997). Learn 2 Teach. Pretoria, RSA: Van Schaik.

[17] Kobo, J.M. (2013). Communicative Language Teaching : A Composition of the Lesotho Form E (English) and South African Grade 12 FAL (English) Curricula. Stellenbosch University.

[18] Latham, B. (2007). Sampling: What is it? Qualitative Research Methods, available at http://webpages. acsttu.edu/rlatham/coursework/5377(Quant)/samplig methodology paper. Pdf (July 16, 2014)

[19] Littlewood, W. (1981). Communicative Language Teaching. Cambridge: Cambridge University Press.

[20] Lungu. E. C. (2006). The Effectiveness of Communicative Approaches and Traditional Methods on Reading and Writing Achievement in English in Grade Eight in Selected Zambian Basic Schools. Unpublished Phd Thesis. The University of Zambia.

[21] Mak'oibila. L. A. \& Onchera., P. O. (2013). English Language Teachers' Choice of Second Language Teaching and Learning Theories in Eldoret Municipality. Kenya. Educational Research (ISSN:2141-5161) Vol. 4 (10) PP 693-701.

[22] Manchishi, P.C and Mwanza, D.S. (2018). Reforming School Experience in Pre-Service

[23] Teacher Preparation for Quality Teacher Graduates. Multidisciplinary Journal of Language and Social Sciences Education, 1 (2): 1-26.

[24] Manchishi, P. C. and Mwanza, D.S. (2016). Teacher Preparation at the University of Zambia.: Is Peer Teaching Still a Useful Strategy? International Journal of Humanities Social Sciences Educations (IJHSSE), 3 (11) 88 - 100.

[25] Manchishi, P.C and Mwanza, D.S. (2013). The University of Zambia School Teaching Experience: Is It Effective? Excellence in Higher Education. 4 (2), 61-77.

[26] Mareva, R. \&Mapako, P. F.(2012) Secondary School Teachers' Concept of Communicative Language Teaching: A Case for Masvingo District- Zimbabwe. In International of Accademic Research in Progressive Education and Development.Vol. 1. No 3. ISSN: 2226-6348.

[27] Mareva, R \&Nyota, S. (2012). Structural or Communicative Approach: A Case of English Language Teaching in Masvingo Urban and Per-Urban Secondary Schools. Internal Journal of English and Literature Vol. 3 (5), 103-111

[28] Maryslessor, O. A., Barasa, P. L. \&Omulando, A. C. (2014). Challenges Teachers Face in the Approach in Teaching listening and Speaking Lessons in Lugrari, Kenya. International Journal of Science and Research (IJSR). Vol. 3. Issue 9

[29] Ministry of Education (1977). Educational Reform: Proposals and Recommendations. Lusaka: Government of the Republic of Zambia Printer.

[30] MOE, (2012). Senior Secondary English Language Syllabus. Lusaka: Zambia Educational Publishing House.

[31] Motsoeneng. S. W. (2003). The Non-effectiveness of the Communicative Language Teaching Approach (CLT) in the Teaching and Language of English as Second Language of English as Second Language (ESL) in Selected Black High Schools in Lower Umfolozi District in Kwazulu-Natal. Unpublished Masters Dissertation.

[32] Munakampe, Y. H. (2005). A Critical Approval of the Communicative Approach in Selected Lusaka Basic Schools. Unpublished Masters' Dissertation. The University of Zambia.

[33] Mwanza, D.S. (2017). Implications of Teachers' Attitudes Towards Unofficial Languages on English Language Teaching in Multilingual Zambia. Journal of Language Studies, 1 (1): 101-124.

[34] Mwanza, D. S. (2017). The Eclectic Approach to Language Teaching: Its Conceptialisation and Misconceptions. International Journal of Humanities Social Sciences and Education (IJHSSE) Volume 4, Issue 2, February 2017, PP 53-67 ISSN 2349-0373.

[35] Mwanza, D.S. (2016). A Critical Reflection on Eclecticism in the Teaching of English Grammar at Selected Zambian Secondary Schools. Unpublished PhD Thesis. University of Western Cape, South Africa.

[36] Neuman, L. W. (2011). Basics of Social Research: Qualitative, Quantitative Approaches (3 ${ }^{\text {rd }}$ ed). New Jersey: Pearson.

[37] Onchera,O.P. \& Manyasi, N. B. (2013). Functional Writing Skills for Effective Communication: The English Language Classroom in Kenya. Journal of Emerging Trends in Educational Research and Policy Studies (JETERAPS) 4(6): 842-847 @ ScholarlinkReasearch Institute Journals (ISSN: 2141-6990). 
Teachers' Understanding and Attitudes towards Communicative Language Teaching Method in ESL Classrooms of Zambia

[38] Ozservik, Z. (2010). The Use of Communicative Language Teaching (CLT): Turkish EFL Teachers' Perceived Difficulties in implementing CLT in Turkey. University of Illinois.

[39] Richards, J. (2006). Today Communicative Language Teaching. Retrieved from http://www. Professorjackrichards.com/pdfs/communicative_language_teaching_today_v2.pdf.

[40] Richards, J. C. \&Rodgrs, T. (1986). Approaches and Methods in Language Teaching.A Description and Analysis. Cambridge University Press.

[41] Ridge, E. (1992). Communicative Language Teaching: Time for Review. Spil Plus, 21: 95-108

[42] Richards, J. C. \& Rodgers.T. (2001). Approaches and Methods in Language Teaching. (2 ${ }^{\text {nd }}$ edition). Cambridge. Cambridge University Press.

[43] Vongxey, H. (2013). The Implementation of Communicative Language Teaching (CLT) in an English Department in Lao Higher Educational Institution: A Case Study. New Zealand: United Institution of Technology.

[44] Wali, N. H. (2009). Eclectism and Language. Al-Faith Journal. No. 39. Diyala University College of Basic Education.

[45] Wodak, R. \& Kendall., G. (2007). Forum Qualitative Social Research.Vol. 8, No. 2, Art. 29.

[46] Xiaoju, L. (1984). In Defence of the Communicative Approach. English Language Teaching Journal, $38(1) 2-13$

\section{AUTHORS' BIOGRAPHY}

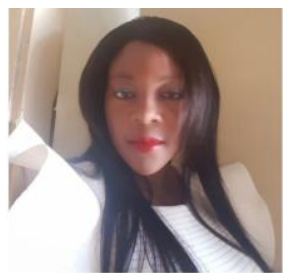

Patricia Makina Zulu is teacher of English and Head of Department at Kansuswa Secondary school in the Copper belt Province of Zambia. She Holds a Masters' Degree in Applied Linguistics from the University of Zambia and she is now in the process of registering for PhD studies in Applied Linguistics at the University of Zambia. Research interests include Language Teaching, Teacher Education and Literacy Studies.

Citation: Patricia Makina Zulu. 'Teachers' Understanding and Attitudes towards Communicative Language Teaching Method in ESL Classrooms of Zambia". International Journal of Humanities Social Sciences and Education (IJHSSE), vol. 6, no.6, 2019, pp. 1-13. doi: http://dx.doi.org/10.20431/2349-0381.0606001.

Copyright: () 2019 Authors. This is an open-access article distributed under the terms of the Creative Commons Attribution License, which permits unrestricted use, distribution, and reproduction in any medium, provided the original author and source are credited. 